\title{
WATER PRODUCTION FUNCTION OF SORGHUM FOR NORTHEAST BRAZIL
}

\section{PREM N. SHARMA* and FAUSTINO B. ALONSO NETO}

Inter-American Institute for Cooperation on Agriculture, Empresa Brasileira de Pesquisa Agropecuária (EMBRAPA), Centro de Pesquisa Agropecuária do Trópico Semi-Arido (CPATSA), Caixa Postal 23, 56.300, Petrolina, PE. (Brazil)

(Accepted 9 July 1985)

\section{ABSTRACT}

Sharma, P.N. and Alonso Neto, F.B., 1986. Water production function of sorghum for Northeast Brazil. Agric. Water Manage., 11: 169-180.

The results of an experiment to determine the water production function of sorghum for Northeast Brazilian conditions are reported. The experiment was designed in two random blocks consisting of four growth stages for irrigation deficit and four levels of nitrogen.

The crop response to water was found to be of quadratic nature. Regression coefficients were developed for each nitrogen and growth stage treatment between water use and grain yields. The most critical stage was found to be the vegetative stage followed by flowering and grain formation stages.

The yield response factors as according to Doorenbos and Kassam were found to vary drastically not only with different nitrogen levels and crop growth stages but also with different irrigation levels. A modified linear equation has been suggested. The coefficients of this modified equation have been determined for all four stages and for the four nitrogen levels for sorghum.

The highest average water use efficiency of $109.3 \mathrm{~kg} \mathrm{ha}^{-1} \mathrm{~cm}^{-1}$ of water and highest obtainable grain yield of $4.92 \mathrm{t} / \mathrm{ha}$ was found to be at $425 \mathrm{~mm}$ of water use and $45 \mathrm{~kg} / \mathrm{ha}$ of nitrogen.

The crop coefficients $\left(K_{\mathrm{c}}\right)$ to compute crop water use from pan evaporation vary between 0.4 and 0.81 with an average for the whole growing period of 0.75 .

\section{INTRODUCTION}

Northeast Brazil is climatically one of the most erratic regions of the world. Supplemental irrigation is being proposed to improve crop production. Such irrigation projects usually involve high expenditures. Often, in the past, projects have been planned without adequate knowledge of water production functions. To fill this gap in information a research project for determining water production functions of major Northeast Brazilian dry land crops was started in 1983. This paper reports the results for sorghum.

\footnotetext{
*Present address: FAO (UN), P.O. Box 345, Vientiane, Laos.
} 


\section{MATERIALS AND METHODS}

The experiment was conducted on an Oxisol. The field was cleared of native forest 2 years before the experiment. After clearing, irrigated tomatoes were grown for 1 year, and then the site was left fallow for a year. Some physical characteristics of the soil on the experimental site are given in Table 1 . Chemical analysis of the soil is reported in Table 2.

The experiment was designed in two randomized blocks consisting of four growth stages and four levels of nitrogen. The growth stages were with irrigation deficits at vegetative, flowering and grain formation stages, and no deficit. The levels of nitrogen applied were $0,45,90$, and $135 \mathrm{~kg} / \mathrm{ha}$. All fields obtained $30 \mathrm{~kg} / \mathrm{ha} \mathrm{K}_{2} \mathrm{O}$ and $90 \mathrm{~kg} / \mathrm{ha}$ of $\mathrm{P}_{2} \mathrm{O}_{5}$. The nitrogen was applied in two parts, one half before sowing and the other half 3 weeks after germination. The method of a line source sprinkler as described by Hanks et al. (1976) was used. Plots of $15 \mathrm{~m} \times 4.5 \mathrm{~m}$ for each of the treat-

\section{TABLE 1}

Some physical properties of the Oxisol of the experimental site (Choudhury and Millar, 1981)

\begin{tabular}{lcccc}
\hline Characteristics & \multicolumn{5}{l}{ Depth interval (cm) } \\
\cline { 2 - 5 } & $0-30$ & $30-60$ & $60-90$ & $90-120$ \\
\hline Texture: & & & & \\
$\quad$ Gross sand (\%) & 4 & 5 & 3 & 3 \\
Fine sand (\%) & 87 & 81 & 79 & 76 \\
Silt (\%) & 4 & 5 & 6 & 8 \\
Clay (\%) & 5 & 9 & 12 & 13 \\
& & & & \\
Textural classification & Sandy & Sandy & Loamy & Loamy \\
(USDA) & & loam & sand & sand \\
Apparent density (g/cm ${ }^{3}$ ) & 1.62 & 1.68 & 1.64 & 1.62 \\
$\quad$ Real density (g/cm $\left.{ }^{3}\right)$ & 2.72 & 2.74 & 2.74 & 2.82 \\
Field capacity (\%) & 8.94 & 9.00 & 9.20 & 9.00 \\
Permanent wilting & & & & \\
$\quad$ point (15 atm) (\%) & 1.84 & 2.52 & 3.07 & 3.22 \\
\hline
\end{tabular}

TABLE 2

Chemical properties of the experimental site

\begin{tabular}{|c|c|c|c|c|c|c|c|c|}
\hline \multirow{2}{*}{$\begin{array}{l}\mathrm{pH} \\
\mathrm{H}_{2} \mathrm{O} \\
(1: 2.5)\end{array}$} & \multirow{2}{*}{$\begin{array}{l}\text { Electrical } \\
\text { conductivity } \\
\left(25^{\circ} \mathrm{C}\right) \text {, Sat. Ext. } \\
\left(\mathrm{S} \mathrm{m}^{-1}\right)\end{array}$} & \multicolumn{5}{|c|}{$\begin{array}{l}\text { Exchangeable cations } \\
\text { (meq/100 g of soil) }\end{array}$} & \multirow[t]{2}{*}{$\begin{array}{l}\mathrm{Al}^{+3} \\
(\mathrm{meq})\end{array}$} & \multirow[t]{2}{*}{$\begin{array}{l}\mathrm{P} \\
(\mathrm{ppm})\end{array}$} \\
\hline & & $\mathrm{Ca}^{2+}$ & $\mathrm{Mg}^{2+}$ & $\mathrm{Na}^{+}$ & $\mathrm{K}^{+}$ & $\mathbf{S}$ & & \\
\hline 4.8 & 0.025 & 0.8 & 0.4 & 0.01 & 0.16 & 1.4 & 0.36 & 6.5 \\
\hline
\end{tabular}


ments were laid out to give two replications per block by locating one replication on either side of the sprinkler line. Wind velocities often exceeded $300 \mathrm{~km} /$ day, therefore the upper wind replication of each block had to be rejected since this replication could only be partially wetted. Figure 1 shows a typical irrigation distribution pattern. Thus the analysis presented here is actually for one replication. The layout for one of the growth stage treatments is shown in Fig. 2. Other growth stage treatments were similar.

The experiment was carried out using the IPA 7301011 granifero variety of sorghum because this variety is one of the highest grain yielding varieties of the region. The plant population was maintained at 100000 plants per ha. Each plot consisted of six rows spaced at $75 \mathrm{~cm}$. Two of these six rows on the sides were borders. Six levels of irrigation and soil moisture to 120 $\mathrm{cm}$ soil depth were monitored: $1.25,3.75,6.25,8.75,11.25$, and $13.75 \mathrm{~m}$, from the line source. Wind velocities, rainfall, daily evaporation rates and mean relative humidity were obtained from the nearby meteorological station of the irrigation research centre and used for irrigation scheduling.

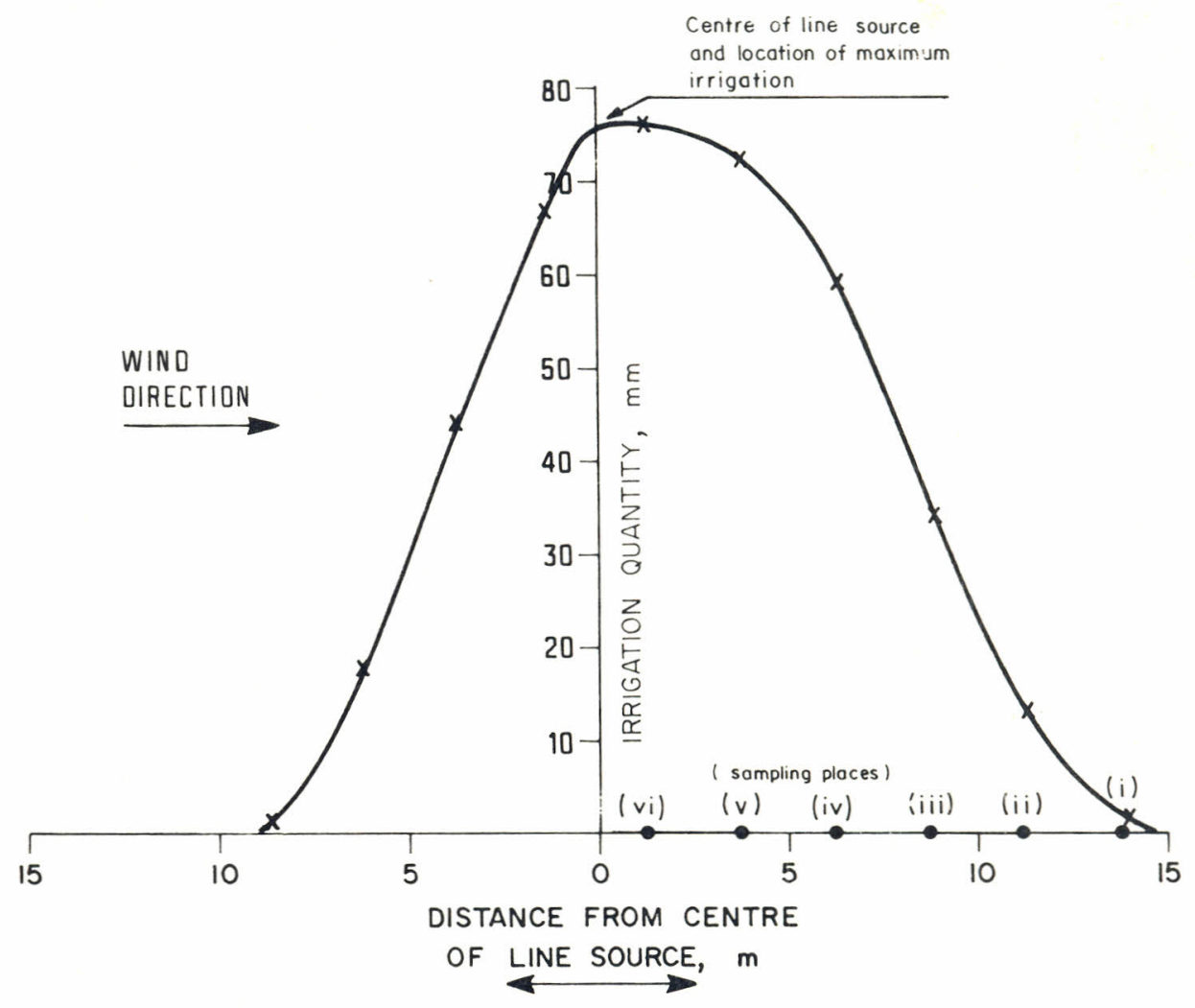

Fig. 1. Typical irrigation water distribution pattern from centre of line source (irrigation of 31 October 1983). 
In total eight irrigations were given. The first three irrigations totalling $84.2 \mathrm{~mm}$ were given uniformly on 23 August, 30 August and 9 September 1983 for establishing the crop. The other five irrigations continuously varied with distance from the centre of the line source and were given on 22 September, 7 and 19 October, 1 and 19 November 1983, respectively. All irrigations were scheduled at 50\% moisture depletion level in the first

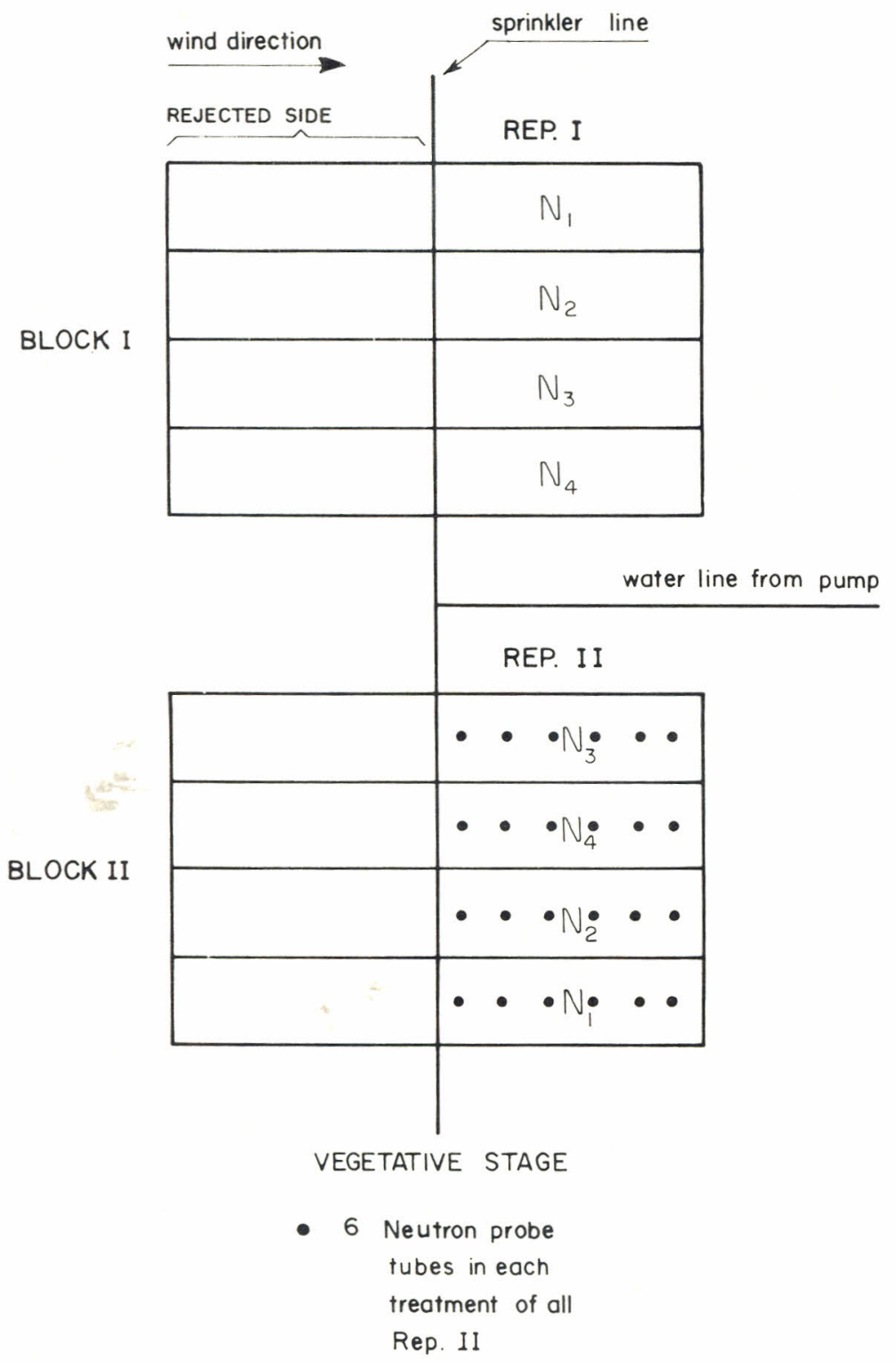

Fig. 2. Lay-out sketch of the vegetative stage of the experiment. 
$100 \mathrm{~cm}$ of soil, at the point of maximum water application which is at the centre of the line source. The pan and crop coefficients used were those recommended by Doorenbos and Kassam (1979). Deficits at a particular stage were obtained by skipping the irrigation on that stage while all other stages were irrigated. The 4 th irrigation (30 days after planting) was skipped for a deficit in the vegetative stage. The 6 th (56 days after planting) and 7th (68 days after planting) were skipped to give the deficits in the flowering and grain formation stages. The no deficit stage got all eight irrigations. The crop was harvested after 100 days.

Irrigation quantity was monitored by cans and soil moisture was monitored in one replicate of each of the four growth stages for each nitrogen treatment by neutron probes at six locations.

The water use was calculated by summing the irrigation quantity applied at the six locations, soil moisture contribution and rainfall. Deep percolation was monitored by taking soil moisture readings after an irrigation between 90 and $120 \mathrm{~cm}$ depth. Because soil water at this depth never reached field capacity there were no deep percolation losses.

A total of $61.9 \mathrm{~mm}$ rainfall was recorded. Except for one event of 39 $\mathrm{mm}$ in the last week of the experiment, all rainfall was in small quantities. There was no runoff loss from any rainfall event. Crop yield samples taken from plots of $3 \mathrm{~m} \times 1 \mathrm{~m}$ for grain and fodder were collected at the same six places of each treatment.

\section{RESULTS AND DISCUSSION}

The observed sorghum grain yield $(y)$ at different water use $(Q)$ levels for the four stages $(T)$ and for the four nitrogen levels $(N)$ have been reported in detail elsewhere (Sharma, 1985). For brevity a summery of the observed data is given here in Table 3. Table 3 also shows the range of variation of the FAO yield response factor $(K)$ and the water use efficiency within the given water use and yield data range.

\section{Yield response to various variables}

The nature of crop response (yield) to water use was found to be of quadratic nature. Regression coefficients for the quadratic equations developed for different stages, $T$ (days) at different levels of nitrogen, $N$ $(\mathrm{kg} / \mathrm{ha})$ between grain yield, $y(\mathrm{~kg} / \mathrm{ha}$, dependent variable) and water use, $Q$ (mm, independent variable), and the values of $R^{2}$ and standard error $(\sigma)$ for each regression equation are given in Table 4 . The coefficients which have an asterisk $(\star)$ on $N$ give negative values of $y$ at very low water use hence should not be used at such low values of $Q$.

When $N(\mathrm{~kg} / \mathrm{ha})$ is introduced as another independent variable, the multiple regression analysis gives the following equation (significant at $1 \%$ level) for different stages: 
Vegetative stage $(T=30$ days $)$ :

$y=-83.24+2.06 N-0.11 N^{2}-0.75 Q+0.01 Q^{2}-0.005 N Q$

$R^{2}=0.86, \sigma=182.8$

Flowering stage $(T=56$ days $)$ :

$y=-1778.82+0.21 N+0.046 N^{2}+9.61 Q-0.003 Q^{2}-0.21 N Q$

$R^{2}=0.76, \sigma=320.74$

Grain formation stage ( $T=68$ days):

$y=-4855.47-16.20 N+0.14 N^{2}+35.51 Q-0.033 Q^{2}-0.037 N Q$

$R^{2}=0.80, \sigma=507.01$

No deficit $(T=100$ days $)$ :

$y=-4677.61+3.92 N-0.026 N^{2}+30.38 Q-0.025 Q^{2}-0.015 N Q$

$R^{2}=0.77, \sigma=792.11$

\section{TABLE 3}

Summary of the observed water use and grain yield data, and variation of FAO yield response factor and water use efficiency within the observed data range

\begin{tabular}{|c|c|c|c|c|c|c|c|c|c|}
\hline \multirow{3}{*}{$\begin{array}{l}\text { Water deficit } \\
\text { stage, } T \text { (days) }\end{array}$} & \multirow{3}{*}{$\begin{array}{l}\text { Nitrogen } \\
\text { level, } N \\
(\mathrm{~kg} / \mathrm{ha})\end{array}$} & \multicolumn{8}{|c|}{ Range of observed values (rounded) } \\
\hline & & \multicolumn{2}{|c|}{$\begin{array}{l}\text { Water, } \\
\text { use, } Q \\
(\mathrm{~mm})\end{array}$} & \multicolumn{2}{|c|}{$\begin{array}{l}\text { Grain } \\
\text { yield, } y \\
(\mathrm{~kg} / \mathrm{ha})\end{array}$} & \multicolumn{2}{|c|}{$\begin{array}{l}\text { FAO yield } \\
\text { response } \\
\text { factor, } K\end{array}$} & \multicolumn{2}{|c|}{$\begin{array}{l}\text { Water use } \\
\text { efficiency } \\
\left(\mathrm{kg} \mathrm{ha}^{-1} \mathrm{~cm}^{-1}\right. \\
\text { of water })\end{array}$} \\
\hline & & from & to & from & to & from & to & from & to \\
\hline \multirow{4}{*}{$\begin{array}{l}\text { Vegetative } \\
(30)\end{array}$} & 0 & 131 & 409 & 93 & 1187 & 1.4 & 21.2 & 7.1 & 29 \\
\hline & 45 & 152 & 401 & 17 & 1067 & 1.6 & 13.9 & 1.1 & 26.6 \\
\hline & 90 & 151 & 400 & 47 & 1593 & 1.5 & 11.7 & 3.1 & 39.8 \\
\hline & 135 & 144 & 388 & 37 & 823 & 1.5 & 9.7 & 2.5 & 21.2 \\
\hline \multirow{4}{*}{$\begin{array}{l}\text { Flowering } \\
\quad(56)\end{array}$} & 0 & 213 & 413 & 0 & 1903 & 2.0 & 21.5 & 0.0 & 46.1 \\
\hline & 45 & 220 & 423 & 0 & 1687 & 2.1 & 139.5 & 0.0 & 39.9 \\
\hline & 90 & 177 & 419 & 0 & 1880 & 1.7 & 44.5 & 0.0 & 44.9 \\
\hline & 135 & 169 & 422 & 0 & 1460 & 1.7 & 114.9 & 0.0 & 34.6 \\
\hline \multirow{4}{*}{$\begin{array}{l}\text { Grain } \\
\text { formation } \\
\quad(68)\end{array}$} & 0 & 172 & 333 & 60 & 3333 & 0.85 & 1.5 & 3.5 & 100.2 \\
\hline & 45 & 171 & 369 & 0 & 2083 & 1.7 & 4.47 & 0.0 & 70.1 \\
\hline & 90 & 232 & 369 & 50 & 2720 & 1.7 & 3.39 & 2.2 & 73.8 \\
\hline & 135 & 189 & 338 & 136 & 2037 & 1.75 & 2.87 & 7.23 & 60.24 \\
\hline \multirow{4}{*}{$\begin{array}{l}\text { No deficit } \\
\quad(100)\end{array}$} & 0 & 205 & 427 & 10 & 3903 & 1.9 & 39.4 & 0.5 & 91.46 \\
\hline & 45 & 200 & 462 & 666 & 3453 & -26.1 & $\infty$ & 33.0 & 115.9 \\
\hline & 90 & 177 & 442 & 87 & 3000 & 1.7 & -9.68 & 4.9 & 67.92 \\
\hline & 135 & 161 & 449 & 17 & 3067 & 1.6 & -7.89 & 1.0 & 82.39 \\
\hline
\end{tabular}


Finally the growth stage represented by time of the beginning of deficit was also introduced as an independent variable along with nitrogen and water use. The quadratic multiple regression analysis nature gives the following equation (significant at $1 \%$ level):

$$
\begin{aligned}
y= & -1526.55-26.71 T-0.03 T^{2} \\
& -2.66 N+0.041 N^{2} \\
& +14.17 Q-0.028 Q^{2} \\
& -0.05 T N+0.17 T Q-0.008 T N Q
\end{aligned}
$$

$R^{2}=0.75, \sigma=604.91$

These multiple regressions in general are valid within the range of data. However, sometimes these equations give negative values of $y$ for the lowest values of water use and should be used with caution.

\section{Water use efficiency (WUE)}

The water use efficiency, calculated by dividing the grain yield by the quantity of water ( $\mathrm{kg} \mathrm{ha}^{-1} \mathrm{~cm}^{-1}$ of water), give the highest values for no

\begin{tabular}{|c|c|c|c|c|c|c|}
\hline \multirow{2}{*}{$\begin{array}{l}\text { Water deficit } \\
\text { stage, } T \text { (days) }\end{array}$} & \multirow{2}{*}{$\begin{array}{l}\text { Nitrogen } \\
\text { level, } N \\
(\mathrm{~kg} / \mathrm{ha})\end{array}$} & \multicolumn{3}{|c|}{ Regression coefficients } & \multirow[b]{2}{*}{$R^{2}$} & \multirow{2}{*}{$\begin{array}{l}\text { Standard } \\
\text { error } \\
(\sigma)\end{array}$} \\
\hline & & $a$ & $b$ & $c$ & & \\
\hline \multirow{4}{*}{$\begin{array}{l}\text { Vegetative } \\
\text { (30) }\end{array}$} & 0 & 267.36 & -3.73 & -0.016 & 0.94 & 131.83 \\
\hline & 45 & -943.72 & 7.18 & 0.006 & 0.86 & 188.49 \\
\hline & 90 & 892.67 & -9.68 & 0.03 & 0.91 & 182.55 \\
\hline & 135 & -538.87 & 4.00 & -0.001 & 0.9 & 132.69 \\
\hline \multirow{4}{*}{$\begin{array}{l}\text { Flowering } \\
\quad(56)\end{array}$} & 0 & -1126.83 & 5.06 & 0.004 & 0.84 & 296.21 \\
\hline & 45 & -1534.86 & 7.85 & -0.003 & 0.75 & 335.60 \\
\hline & 90 & 151.18 & -3.67 & 0.016 & 0.69 & 444.22 \\
\hline & 135 & -2403.02 & 18.12 & -0.02 & 0.94 & 136.17 \\
\hline \multirow{4}{*}{$\begin{array}{l}\text { Grain, } \\
\text { formation } \\
\quad(68)\end{array}$} & 0 & -7721.99 & 58.16 & -0.076 & 0.87 & 548.41 \\
\hline & 45 & -2515.14 & 15.32 & -0.005 & 0.93 & 278.95 \\
\hline & 90 & -760.48 & 45.09 & -0.05 & $0.65^{a}$ & 651.18 \\
\hline & 135 & -4362.19 & 30.40 & -0.035 & $0.71^{\mathrm{a}}$ & 518.49 \\
\hline \multirow{4}{*}{$\begin{array}{l}\text { No deficit } \\
\quad(100)\end{array}$} & 0 & -8265.87 & 55.02 & -0.065 & 0.73 & 867.44 \\
\hline & 45 & -9919.42 & 66.00 & 0.079 & 0.76 & 950.71 \\
\hline & $90 *$ & -1834.3 & 8.77 & 0.006 & 0.96 & 282.23 \\
\hline & $135 *$ & -2013.1 & 10.26 & 0.004 & $0.92^{\mathrm{b}}$ & 612.07 \\
\hline
\end{tabular}

\section{TABLE 4}

Regression coefficients of the quadratic equation $\left(Y=a+b Q+c Q^{2}\right)$ of yield response to water ( $a, b$ and $c$ are the regression coefficients)

a Significant at $5 \%$ level.

${ }^{\mathrm{b}}$ Significant at $10 \%$ level. All others significant at less than $1 \%$ level.

* Coefficient give negative values of $y$ for first data set (lowest water level in Table 3). 
deficit followed by a deficit at the grain filling stage as shown in Table 3 . The WUE for both vegetative and flowering stage were low. The highest average (of the two replicates) water use efficiency was observed to be $109.3 \mathrm{~kg} \mathrm{ha}^{-1} \mathrm{~cm}^{-1}$ of water at $425 \mathrm{~mm}$ water use for $45 \mathrm{~kg} / \mathrm{ha}$ applied nitrogen and the no deficit stage. The average (of the two replicates) highest grain yield was also obtained at the same point. From the values of WUE obtained it can be concluded that if available water is limited, the deficit should not be allowed to occur during vegetative and flowering stages.

\section{Yield response factors $(K)$}

Doorenbos and Kassam (1979) used the following equation for predicting relative yield decrease for relative evapotranspiration deficit:

$\left(1-y / y_{\mathrm{m}}\right)=K\left(1-Q / Q_{\mathrm{m}}\right)$

where $y$ is actual yield $(\mathrm{kg} / \mathrm{ha})$ and $Q$ is the corresponding water use or actual evapotranspiration $(\mathrm{mm}), y_{\mathrm{m}}$ is maximum obtainable yield $(\mathrm{kg} / \mathrm{ha})$, and $Q_{\mathrm{m}}$ is the corresponding maximum evapotranspiration $(\mathrm{mm})$. The coefficient $K$ is called the yield response factor.

It is to be understood that the maximum yield, $y_{\mathrm{m}}$ is defined (quoted from Doorenbos and Kassam, 1979) as: "The harvested yield of a high producing variety, well adapted to the given growing environment, including the time available to reach maturity, under conditions where water, nutrients and pests and diseases do not limit yield."

Thus $y_{\mathrm{m}}$ is the global maximum yield having only one value. It should not be confused with the highest yield at different fertility or growth treatments. Hence the term $\left(1-y / y_{\mathrm{m}}\right)$ is the relative yield decrease and (1$\left.Q / Q_{\mathrm{m}}\right)$ is the relative evapotranspiration deficit. The factor $K$ relates the two. Doorenbos and Kassam (1979) consider equation (1) to be valid up to $50 \%$ relative evapotranspiration deficit.

Taking a closer look at equation (1) it was found that it is not valid when fertility and growth stages are variable. For example, it is obvious that even if relative evapotranspiration deficit is zero but the fertility level is below (or above) the optimum fertility required, there will be a substantial yield decrease. Similarly when water is not available at a certain critical growth stage but overall there is no relative evapotranspiration deficit, there shall be a substantial yield decrease. Equation (1) does not take account of this.

The maximum obtainable yield was taken as $4.92 \mathrm{t} / \mathrm{ha}$ at $425 \mathrm{~mm}$ of water use from our data. The research station that developed the variety gives for the genetic yield potential $5 \mathrm{t} / \mathrm{ha}$, which is very close to our maximum. When yield response factors are calculated by equation (1), they are found to vary within various stages, nitrogen and water levels, (this is demonstrated in Table 3); according to equation (1) there should be a fixed value or at most a narrow range for each stage and nitrogen level. 
Similar variations were also found for maize by the first author who carried out similar experiments at the same site in the year after the sorghum experiment reported here (Sharma and Pereira, 1985). This problem can be taken care of if equation (1) is modified as follows:

$\left(1-y / y_{m}\right)=K_{1}+K_{2}\left(Q / Q_{m}\right)$

where $K_{1}$ and $K_{2}$ are modified yield response factors which are to be determined by experimentation. Linear regression analysis of the data was carried out to give values of $K_{1}$ and $K_{2}$. These values are reported in Table 5. Equation (2) should also be valid up to about $50 \%$ water deficit.

\section{TABLE 5}

Modified yield response factors for sorghum at different nitrogen levels and different growth stages

\begin{tabular}{|c|c|c|c|c|c|c|}
\hline \multirow[t]{2}{*}{$\begin{array}{l}\text { Water deficit } \\
\text { stage, } T \text { (days) }\end{array}$} & \multirow{2}{*}{$\begin{array}{l}\text { Nitrogen } \\
\text { level, } N \\
(\mathrm{~kg} / \mathrm{ha})\end{array}$} & \multicolumn{2}{|c|}{$\begin{array}{l}\text { New yield response } \\
\text { factors }^{\text {a }}\end{array}$} & \multirow[t]{2}{*}{$R^{2}$} & \multirow{2}{*}{$\begin{array}{l}\text { Standard } \\
\text { error } \\
(\sigma)\end{array}$} & \multirow{2}{*}{$\left(K_{1}+1 / 2 K_{2}\right)$} \\
\hline & & $K_{1}$ & $K_{2}$ & & & \\
\hline \multirow{4}{*}{$\begin{array}{c}\text { Vegetative } \\
(30)\end{array}$} & 0 & 0.75 & 0.34 & 0.76 & 0.05 & 0.92 \\
\hline & 45 & 0.74 & 0.37 & 0.56 & 0.08 & 0.93 \\
\hline & 90 & 0.67 & 0.55 & 0.75 & 0.08 & 0.95 \\
\hline & 135 & 0.81 & 0.30 & 0.83 & 0.03 & 0.96 \\
\hline \multirow{4}{*}{$\begin{array}{l}\text { Flowering } \\
\quad(56)\end{array}$} & 0 & 0.71 & 0.44 & 0.53 & 0.09 & 0.93 \\
\hline & 45 & 0.73 & 0.49 & 0.80 & 0.06 & 0.98 \\
\hline & 90 & 0.71 & 0.52 & 0.67 & 0.09 & 0.97 \\
\hline & 135 & 0.72 & 0.42 & 0.85 & 0.04 & 0.93 \\
\hline \multirow{4}{*}{$\begin{array}{l}\text { Grain } \\
\quad \text { formation } \\
\quad(68)\end{array}$} & 0 & 0.0 & 1.68 & 0.79 & 0.14 & 0.84 \\
\hline & 45 & 0.37 & 1.07 & 0.89 & 0.07 & 0.91 \\
\hline & 90 & 0.39 & 1.03 & 0.69 & 0.11 & 0.91 \\
\hline & 135 & 0.32 & 1.10 & 0.66 & 0.14 & 0.87 \\
\hline \multirow{4}{*}{$\begin{array}{l}\text { No deficit } \\
(100)\end{array}$} & 0 & 0.33 & 1.13 & 0.56 & 0.22 & 0.90 \\
\hline & 45 & 0.33 & 0.98 & 0.51 & 0.23 & 0.82 \\
\hline & 90 & 0.41 & 1.02 & 0.97 & 0.05 & 0.92 \\
\hline & 135 & 0.33 & 1.10 & 0.9 & 0.09 & 0.88 \\
\hline
\end{tabular}



The new yield response factor $K_{1}$ gives the minimum relative yield decrease which takes place when the nitrogen level is different from the optimum or when one of the critical growth stages suffers from water deficit. The factor $K_{2}$ is a multiplier to the relative yield decrease due to overall change in water level and is similar to the $K$ factor of Doorenbos and Kassam (1979). The higher the values of $K_{1}$ the more critical is the growth stage for irrigation. Inversely the lower the values of $K_{1}$, the less the rela- 
tive yield decreases. From the experimental results the importance of deficits in the growth stages can be ranked as:

vegetative $\geqq$ flowering $>$ grain filling $>$ no deficit stage

where the vegetative and flowering stages are almost equally critical followed by the grain filling stage.

In the grain filling stage and $0 \mathrm{~kg} / \mathrm{ha}$ nitrogen the value of $K_{1}$ is zero, but $K_{2}$ has the highest value $(=1.68)$. As equation $(2)$ is valid only up to $50 \%$ ET deficit, the combined effect of $K_{1}$ and $K_{2}$ can have a maximum value of $\left(K_{1}+1 / 2 K_{2}\right)$ only, which gives the maximum yield response factor of 1.0. In Table 5 the value $\left(K_{1}+1 / 2 K_{2}\right)$ is also shown. The ranking of critical stages by this factor is the same as for $K_{1}$ as already discussed. The lowest value of $\left(K_{1}+1 / 2 K_{2}\right)$ is for $45 \mathrm{~kg} / \mathrm{ha}$ nitrogen and no deficit (also $K_{1}$ has one of the lowest values for this treatment). This is the optimum combination of nitrogen and irrigation because it will have the lowest yield deficit at various evapotranspiration deficit levels.

Theoretically, $K_{1}$ for the optimum combination should be zero. However in practice even with the best treatments this theoretical value can hardly be achieved. The maximum potential yield is very rarely obtainable. For this reason many researchers in irrigation systems management have questioned the validity of theoretical water production functions (Levine, 1980).

From Table 5 all possible combinations can be made. For example if shortage of water is expected it will be best to allow that shortage in the grain filling stage and not apply any nitrogen since it has the next to lowest value of $\left(K_{1}+1 / 2 K_{2}\right)$. This is not surprising since many researchers in Northeast brazil have also found that many dry land crops under dry conditions do not respond to nitrogen (Richardson and Van Vught, 1965; Poultrey, 1968).

\section{Crop coefficients $\left(K_{\mathrm{c}}\right)$}

The crop coefficients $K_{\mathrm{c}}$ are used for irrigation scheduling together with pan evaporation data. A sample calculation is given in Table 6 for conditions which give maximum WUE and yield and hence optimum water use. The first four growth periods are each after an interval of two successive irrigations while the last growth period (harvest) is between the 8th irrigation and date of harvest. These calculated crop coefficients $K_{\mathrm{c}}$ are about the same as those given by Doorenbos and Kassam (1979) but the mid-season value is lower than the FAO value.

Table 7 gives the values of $K_{\mathrm{c}}$ for different nitrogen levels, calculated in the same way for all other values of $N$. Crop coefficients for $N=0 \mathrm{~kg} / \mathrm{ha}$ and $N=45 \mathrm{~kg} / \mathrm{ha}$ for different growth periods are about equal. The $K_{\mathrm{c}}$ values for $N=90 \mathrm{~kg} / \mathrm{ha}$ and $N=135 \mathrm{~kg} / \mathrm{ha}$ are initially the same as for the other $N$ levels, but are lower between 18 and 85 days and higher from 
TABLE 6

Crop coefficients $K_{\mathrm{c}}$ for sorghum at $N=45 \mathrm{~kg} / \mathrm{ha}$, no deficit stage and maximum average water utilization efficiency and yield

\begin{tabular}{|c|c|c|c|c|c|c|}
\hline $\begin{array}{l}\text { Crop develop- } \\
\text { ment periods }\end{array}$ & Initial & $\begin{array}{l}\text { Crop } \\
\text { development }\end{array}$ & $\begin{array}{l}\text { Mid- } \\
\text { season }\end{array}$ & $\begin{array}{l}\text { Late } \\
\text { season }\end{array}$ & Harvest & Total \\
\hline $\begin{array}{l}\text { Duration from } \\
\text { planting (days) }\end{array}$ & $0-17$ & $18-44$ & $45-68$ & $69-85$ & $86-106$ & $0-106$ \\
\hline Irrigation (mm) & 59 & 96 & 123 & 69 & 55 & 402 \\
\hline $\begin{array}{l}\text { Soil moisture } \\
\text { contribution } \\
\text { to } Q \\
(N=45 \mathrm{~kg} / \mathrm{ha})\end{array}$ & -17 & 10 & 10 & -3 & -48 & -39 \\
\hline Rainfall (mm) & - & - & 2.6 & 11.4 & 47.9 & 61.9 \\
\hline $\begin{array}{l}\text { Actual evapo- } \\
\text { transpiration, } \\
Q(\mathrm{~mm})^{\mathrm{a}} \\
(N=45 \mathrm{~kg} / \mathrm{ha})\end{array}$ & 41.7 & 106.3 & 135.8 & 77.5 & 54.5 & $\begin{array}{l}424.6 \\
-3\end{array}$ \\
\hline $\begin{array}{l}\text { Pan evapora- } \\
\text { tion, EV }(\mathrm{mm})\end{array}$ & 158.9 & 221.3 & 256.8 & 162.4 & 168.6 & 868.1 \\
\hline $\begin{array}{l}\text { Pan coefficient, } \\
K_{\mathrm{p}}^{\mathrm{b}}\end{array}$ & 0.65 & 0.65 & 0.65 & 0.65 & 0.65 & 0.65 \\
\hline $\begin{array}{l}\text { Ref. crop ET, } \\
\mathrm{ET}_{0}=K_{\mathrm{p}} \mathrm{EV}(\mathrm{mm}\end{array}$ & 103.3 & 143.9 & 167 & 105.5 & 109.6 & 564.3 \\
\hline $\begin{array}{l}K_{\mathrm{c}}=Q / \mathrm{ET}_{0} \\
\text { (calculated) }\end{array}$ & 0.40 & 0.74 & 0.81 & 0.73 & 0.5 & 0.75 \\
\hline FAO $K_{\mathrm{c}}$ values & 0.3 & 0.7 & 1.05 & 0.75 & 0.5 & 0.75 \\
\hline
\end{tabular}

${ }^{\mathrm{a}} Q=$ (irrigation + soil moisture contribution + rainfall); there was no deep percolation and no runoff.

${ }^{\mathrm{b}}$ For moderate wind velocities $(175-425 \mathrm{~km} / \mathrm{day})$ and high mean relative humidity $\left(\mathrm{RH}_{\text {mean }} \geqslant 70 \%\right)$, FAO source, Doorenbos and Kassam (1979).

The pan is located in the green grass cover $(<1 \mathrm{~m})$.

\section{TABLE 7}

Values of crop coefficients $K_{\mathrm{c}}$ for sorghum at different nitrogen levels

\begin{tabular}{|c|c|c|c|c|c|c|}
\hline \multirow{2}{*}{$\begin{array}{l}\text { Nitrogen } \\
\text { level, } N \\
\text { (kg/ha) }\end{array}$} & \multicolumn{6}{|c|}{ Value of $K_{\mathrm{c}}$ at different growth periods } \\
\hline & $\begin{array}{l}\text { Initial } \\
(0-17 \\
\text { days })\end{array}$ & $\begin{array}{l}\text { Crop } \\
\text { development } \\
(18-44 \text { days })\end{array}$ & $\begin{array}{l}\text { Mid } \\
\text { season } \\
(45-68 \\
\text { days })\end{array}$ & $\begin{array}{l}\text { Late } \\
\text { season } \\
(69-85 \\
\text { days })\end{array}$ & $\begin{array}{l}\text { Harvest } \\
(86-106 \\
\text { days })\end{array}$ & $\begin{array}{l}\text { Total } \\
\text { period }\end{array}$ \\
\hline 0 & 0.4 & 0.74 & 0.86 & 0.74 & 0.45 & 0.76 \\
\hline 45 & 0.4 & 0.74 & 0.81 & 0.73 & 0.5 & 0.75 \\
\hline 90 & 0.4 & 0.59 & 0.81 & 0.64 & 0.58 & 0.75 \\
\hline 135 & 0.4 & 0.65 & 0.76 & 0.65 & 0.68 & 0.69 \\
\hline FAO values & 0.3 & 0.7 & 1.05 & 0.75 & 0.5 & 0.75 \\
\hline
\end{tabular}


86 to 106 days. This indicates that for all treatments the plant growth starts equally but at higher $N$ levels (i.e. $N=90$ and $135 \mathrm{~kg} / \mathrm{ha}$ ) plant growth is restrained for some unknown reason. Finally plant growth improves which is reflected by higher $K_{\mathrm{c}}$ values between 86 and 106 days; this was also observed in the field. The higher nitrogen levels gave greener plants at harvest time.

\section{CONCLUSIONS}

The multiple regression equations developed can be utilized for economic analysis of irrigation projects. The new yield response factors $\left(K_{1}\right.$ and $\left.K_{2}\right)$ developed here give a better representation of the crop response to water than those suggested earlier by Doorenbos and Kassam (1979). The highest average water use efficiency of $109.3 \mathrm{~kg} \mathrm{ha}^{-1} \mathrm{~cm}^{-1}$ of water and highest grain yield of $4.92 \mathrm{t} / \mathrm{ha}$ was obtained at $425 \mathrm{~mm}$ of water use at $45 \mathrm{~kg} / \mathrm{ha}$ of applied nitrogen for the no water deficit case for which the value of modified crop response factors $K_{1}$ and $K_{2}$ are 0.33 and 0.98 , and the value of $K_{\mathrm{c}}$ for the total period is 0.75 .

\section{ACKNOWLEDGEMENTS}

The authors wish to express their sincere gratitude to Mr. Silvio Climentino for field assistance, Dr. José Ribamar Pereira for suggestions on the fertility aspect of the experiment and Mr. Carlos A.V. de Oliveira for help in statistical analysis.

\section{REFERENCES}

Choudhury, E.N. and Millar, A.A., 1981. Caracterīsticas físico-hïdricas de três Latossolos irrigados do Projeto Bebedouro. EMBRAPA-CPATSA, Pesquisa em Irrigaçao no Trópico Semi-Árido: Solo, Água, Planta, Boletim de Pesquisa, 4 (in Portuguese with English summary).

Doorenbos, J. and Kassam, A.H., 1979. Yield response to water, FAO Irrig. Drain. Pap. 33, Food and Agriculture Organization, Rome, pp. 1, 24, 37-40.

Hanks, R.J., Keller, J., Rasmussen, V.P. and Wilson, G., 1976. Line source sprinkler for continuous variable irrigation crop production studies, Soil Sci. Soc. Am. J., 40 : pp. 426-429.

Levine, G., 1980. The relationship of design, operation and management. In: E.W. Coward, Jr. (Editor), Irrigation and Agricultural Development in Asia - Perspectives from the Social Sciences. Cornell University Press, Ithaca, NY, pp. 51-62.

Poultrey, R.G., 1968. Survey of the San Francisco river basin-Brazil: final report, FAO/ SUDENE, Recife, PE., Brazil, 136 pp.

Richardson, G.E. and Van Vught, C.T., 1965. Survey of the San Francisco river basin (Brazil), final agronomic considerations. FAO/SUDENE, Rome.

Sharma, P.N., 1985. Final Report of Consultancy, submitted to the Inter-American Institute of Cooperation on Agriculture (IICA), Brasilia, DF., Brazil, 31 July.

Sharma, P.N. and Pereira, J.R., 1985. Water production function of maize for northeast Brazil. Braz. J. Agric. Res. (PAB), in press. 